\author{
(c) (i) (8) \\ Jurnal Terapan Manajemen dan Bisnis is licensed under \\ A Creative Commons Attribution-Non_Commercial 4.0 International License
}

\title{
A Study of The Factors That Influence The Level of Consumer Satisfaction Towards The Use of Internet Banking
}

\author{
Vivi ${ }^{1)}$, Novita ${ }^{2)}$ \\ 1) Politeknik Tonggak Equator, Pontianak, Indonesia \\ E-mail: viv_limas@yahoo.com \\ 2) Politeknik Tonggak Equator, Pontianak, Indonesia \\ E-mail: tvincensia@yahoo.com
}

\begin{abstract}
The development of Information and Communication Technology (ICT) has become an integral part of people's life today. Various kinds of business and trade transactions have changed along with the advancement of ICT. One of the sectors that are influenced by the development in information and communication technology is banking. The presence of internet banking has brought more conveniences to the customers in conducting banking transactions anytime and anywhere. However, one of the challenges faced by banks in implementing online banking is the security factor. In addition, consumer satisfaction in conducting internet transactions can be influenced by factors of Technology Acceptance Model (TAM). Technology Acceptance Model (TAM) consists of perceived usefulness and perceived ease of use and excellent service from the provider. The purpose of this study is to determine whether security, perceived usefulness, perceived ease of use, and service quality havepositive influence on internet banking consumer satisfaction. Thetype of research is explanatory research type. The research variables consisting of independent variables are security factor, perceived usefulness, perceived ease of use, and service quality; meanwhile dependent variable is internet banking consumer satisfaction. The sampling technique used is accidental sampling method combined with snowball sampling method. Datais collected through questionnaires and interviews. Methods of data analysis used is Multiple Regression Analysis. The result shows that variables of security, perceived usefulness, perceived ease of use, and service qualitysimultaneously influence internet banking consumer satisfaction. It shows that the four variables positively affect internet banking consumer satisfaction.
\end{abstract}

Keyword : Internet Banking, Consumer Satisfaction

\section{Introduction}

The development of information and communication technology has become an integral part of people's life and has brought changes in various kinds of business and commercial transactions. These changes happened to fulfill the demand of the current era in accordance with consumers' desire. Current information system is used in business to create new products, service market opportunities, and further information system development which cater to business and to support management processes such as planning, controlling, and coordinating. One of the sectors that are influenced by the development in information 
and communication technology is banking. Banking services which were limited to deposits, withdrawals, and other transactions in cash through the counter, have evolved along with the advancement in information and communication technology and came up with ATM, Internet Banking, e-Money, and Mobile Banking. Internet Banking itself is a manifestation of internet utilization by the banks and customers to conduct online banking transactions. The presence of internet banking has brought more conveniences to the customers in conducting banking transactions anytime and anywhere depending on the availability of internet connection by using smartphones, tablets, or laptops. Numerous banks have provided internet baking services.

The features that are offered through internet banking include balance information, account mutation, credit card transaction verification, money transfer, bill payment, purchasing, interest rate information and currency exchange rate. The value of the transactions conducted through online banking and the increase in the number of internet and internet banking users in Indonesia have shown that there are opportunities and challenges for every bank to take advantage of the development in information and communication technology to face global competition. One of the challenges faced by banks in implementing online banking is the security factor. Cybercrime has drawn the attention of various parties especially in the banking world. Besides internet banking, financial services offered by banks that are susceptible to cybercrime include mobile banking, credit card, ATM, and EDC.

Consumers' satisfaction in conducting internet transactions can be influenced by Technology Acceptance Model (TAM). TAM itself is consisted of perceived usefulness factor and perceived ease of use factor. Perceived usefulness is the degree of believe held by people that the use of certain technology or system will improve their working performance (Davis, 1989). Perceived ease of use is the degree of believe held by people that a technology or system is easy to use (Davis, 1989).

One of the strategies to acquire success in banking service industry is by providing excellent and quality services. Therefore, banks place emphasis on product quality by providing featured services and facilities that are not available among the competitors to increase the level of customers satisfaction. This study aims to determine whether such factors as security, perceived usefulness, perceived ease of use, and service quality provide any positive influence towards the satisfaction of consumers who utilize internet banking.

\section{Model and Research Hypotheses.}

The model used in this research can be observed below:

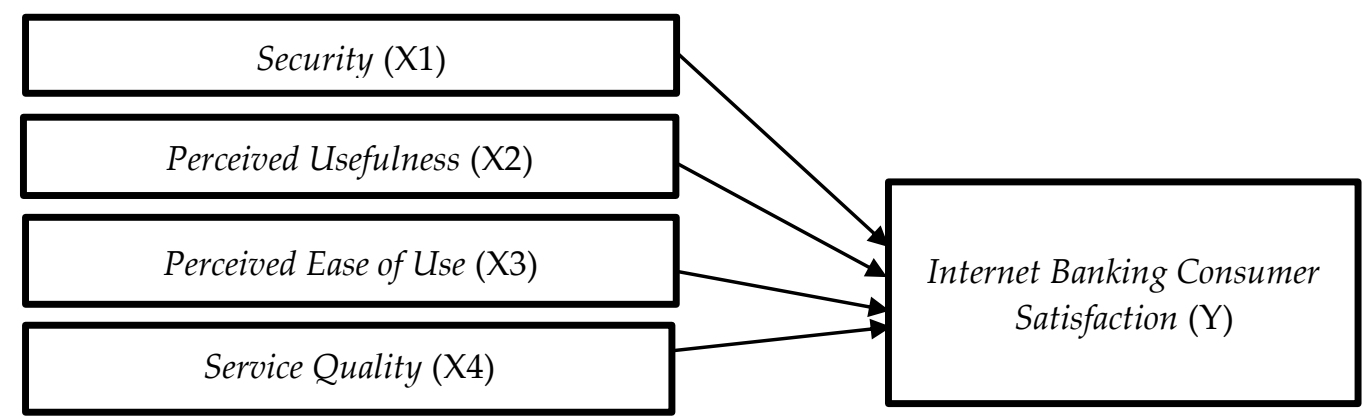

Picture 1.Frame of Research Model 
Based on the outline above, the hypotheses within this research are:

$\mathrm{H}_{1} \quad$ : There are positive influences from security factor, perceived usefulness factor, perceived ease of use factor, and service quality factor simultaneously towards the internet banking consumer satisfaction.

$\mathrm{H}_{2}$ : Security factor positively influences internet banking consumer satisfaction.

$\mathrm{H}_{3} \quad$ : Perceived usefulness factor positively influences internet banking consumer satisfaction.

$\mathrm{H}_{4} \quad$ : Perceived ease of use factor positively influences internet banking consumer satisfaction.

$\mathrm{H}_{5} \quad$ : Service quality factor positively influences internet banking consumer satisfaction.

\section{RESEARCH METHOD}

This is an explanatory research. The population consists of Indonesian people especially those who reside in big cities like Jakarta, Bandung, Surabaya, Medan, and Pontianak and are the customers of banks that provide internet banking facilities. Purposive sampling method is employed to choose the samples based on whether the respondent possesses an active account at a bank providing internet banking, whether the respondent has utilized internet banking before. The purposive sampling method is also combined with snowball sampling method, where first respondent is chosen by using probability method, while the next respondent is acquired based on the information provided by the first respondent. There are 200 respondents who are involved as samples within this research. The data in this research is analyzed quantitatively by using Multiple Regression model.

\section{DISCUSSION}

\section{The result of validity and reliability test.}

The population in this research consists of Indonesian people especially those who reside in big cities like Jakarta, Bandung, Surabaya, Medan, and Pontianak who are the customers of banks that provide internet banking facilities. The samples consist of 200 participants who have active accounts at one of the banks that provide internet banking and have used internet banking.

According to Priyatno (2008:23), validity test is done to investigate the accuracy of an instrument in measuring an object. It is done by using Corrected Item-Total Correlation formula. Two tailed test is used with 0,05 significance level with the following criteria:

1) If $r$ count $\geq r$ table ( 2 tailed test with 0,05 significance) then the instrument or the question items are significantly correlated with total score (declared as valid).

2) If $\mathrm{r}$ count $<\mathrm{r}$ table (2 tailed test with 0,05 significance) then the instrument of the question items are not significantly correlated with total score (declared as invalid).

Table1. The Analysis Result of Independent Variable Validity (Xi)

\begin{tabular}{|c|c|c|c|c|}
\hline & $\begin{array}{l}\text { Scale Mean if } \\
\text { Item Deleted }\end{array}$ & $\begin{array}{l}\text { Scale Variance if } \\
\text { Item Deleted }\end{array}$ & $\begin{array}{c}\text { Corrected Item- } \\
\text { Total } \\
\text { Correlation }\end{array}$ & $\begin{array}{l}\text { Cronbach's } \\
\text { Alpha if Item } \\
\text { Deleted }\end{array}$ \\
\hline x1a & 83.3000 & 63.216 & .635 & .937 \\
\hline$x 1 b$ & 83.3400 & 63.572 & .558 & .938 \\
\hline $\mathrm{x} 1 \mathrm{c}$ & 83.3150 & 62.639 & .682 & .936 \\
\hline$x 1 d$ & 83.7750 & 61.130 & .581 & .939 \\
\hline x1e & 83.4450 & 62.027 & .673 & .936 \\
\hline
\end{tabular}




\begin{tabular}{|c|c|c|c|c|}
\hline$x 2 a$ & 83.0100 & 65.236 & .548 & .938 \\
\hline$x 2 b$ & 82.9850 & 65.000 & .582 & .938 \\
\hline$x 2 c$ & 83.2350 & 63.487 & .598 & .938 \\
\hline$x 2 d$ & 83.3550 & 63.316 & .549 & .939 \\
\hline$x 2 e$ & 83.0800 & 63.923 & .661 & .937 \\
\hline x3a & 83.2850 & 63.340 & .688 & .936 \\
\hline$x 3 b$ & 83.1600 & 63.813 & .682 & .937 \\
\hline$x 3 c$ & 83.2350 & 62.633 & .729 & .936 \\
\hline$x 3 d$ & 83.2900 & 62.127 & .769 & .935 \\
\hline$x 3 e$ & 83.2400 & 62.646 & .715 & .936 \\
\hline$x 4 a$ & 83.4500 & 62.490 & .704 & .936 \\
\hline$x 4 b$ & 83.4550 & 61.867 & .732 & .935 \\
\hline$x 4 c$ & 83.5800 & 61.531 & .673 & .936 \\
\hline$x 4 d$ & 83.4600 & 62.079 & .702 & .936 \\
\hline$x 4 e$ & 83.5900 & 62.213 & .562 & .939 \\
\hline
\end{tabular}

From the output in table 1, the correlation value can be observed at Corrected ItemTotal Correlation which will then be compared with the value of $r$ table. The $r$ table which is acquired at 0,05 significance with two tailed test and where the amount of data $(n)=200$ is 0,139 . The analysis shows that all items have correlation values higher than 0,139 , hence it can be concluded that all objects of the instrument are valid.

Table 2. Analysis Result of Dependent Variable Validity $(\mathrm{Y})$

\begin{tabular}{|c|c|c|c|c|}
\hline & $\begin{array}{l}\text { Scale Mean if } \\
\text { Item Deleted }\end{array}$ & $\begin{array}{c}\text { Scale Variance if } \\
\text { Item Deleted }\end{array}$ & $\begin{array}{c}\text { Corrected Item- } \\
\text { Total } \\
\text { Correlation } \\
\end{array}$ & $\begin{array}{c}\text { Cronbach's } \\
\text { Alpha if Item } \\
\text { Deleted }\end{array}$ \\
\hline y1 & 17.5500 & 4.128 & .814 & .870 \\
\hline$y^{2}$ & 17.6200 & 4.187 & .770 & .878 \\
\hline y3 & 17.7200 & 4.002 & .700 & .893 \\
\hline y4 & 17.6050 & 3.939 & .832 & .864 \\
\hline y5 & 17.7250 & 3.818 & .703 & .896 \\
\hline
\end{tabular}

From the output in table 2, the correlation value can be observed at Corrected ItemTotal Correlation which will then be compared with the value of $r$ table. The $r$ table which is acquired at 0,05 significance with two tailed test and where the amount of data $(n)=200$ is 0,139 . The analysis shows that all items have correlation values higher than 0,139 , hence it can be concluded that all objects of the instrument are valid.

The reliability test is done to investigate the consistency of measuring tools, whether they will remain reliable and consistent if the measurement is repeated. The measurement uses reliability test with Cronbach's Alpha method. According to Sekaran (in Priyatno, 2008) a questionnaire can be considered reliable if the value of Cronbach's Alpha > 0,6.

Table 3. Analysis Result of Independent Variable Reliability (Xi)

\begin{tabular}{rr}
\hline Cronbach's Alpha & N of Items \\
\hline .940 & 20 \\
\hline
\end{tabular}


The result of the analysis shows that the value of Alpha for the independent variable is 0,940. Hence it can be concluded that all objects of the instrument are reliable.

Table 4. Analysis Result of Dependent Variable Reliability (Y)

\begin{tabular}{rr} 
Cronbach's Alpha & N of Items \\
\hline .902 & 5
\end{tabular}

The result of the analysis shows that the value of Alpha for the dependent variable is 0,902 . Hence it can be concluded that all objects of the instrument are reliable.

\section{Classic Assumption Test}

To fulfill the condition of Best Linear Unbiased Estimator (BLUE) requires the execution of econometric evaluation towards regression equation model, which is consisted of multicollinearity test, heteroscedasticity test, and autocorrelation test.

\section{Multicollinearity Test}

Multicollinearity test is used to investigate the presence of deviation in multicollinearity classic assumption that is the presence of linear connection between independent variables in the regression model. The required condition in the regression model is the absence of multicollinearity.

According to Santoso (in Duwi Priyatno, 2008: 39), in general if VIF is bigger than 5, then there is a multicollinearity problem between the variable and other independent variables. The result of multicollinearity test can be seen in Table 5 below:

Table 5. Multicollinearity Test Result

\begin{tabular}{|c|c|c|c|c|c|c|}
\hline \multicolumn{7}{|c|}{ Coefficients $^{a}$} \\
\hline \multirow{2}{*}{\multicolumn{2}{|c|}{ Model }} & \multicolumn{3}{|c|}{ Correlations } & \multicolumn{2}{|c|}{ Collinearity Statistics } \\
\hline & & Zero-order & Partial & Part & Tolerance & VIF \\
\hline \multirow[t]{4}{*}{1} & Security & .720 & .408 & .248 & .489 & 2.043 \\
\hline & Perceived usefulness & .634 & .106 & .059 & .451 & 2.216 \\
\hline & Perceived ease of use & .708 & .300 & .175 & .368 & 2.718 \\
\hline & Service quality & .745 & .243 & .139 & .344 & 2.905 \\
\hline
\end{tabular}

Table 5 shows that the values of variance inflation factor (VIF) of the independent variables $(\mathrm{Xi})$ are smaller than 5 , hence it can be declared that there is no multicollinearity among the free variables.

\section{Heteroscedasticity Test}

Heteroscedasticity test is useful to investigate the presence of deviation in heteroscedasticity classic assumption, that is the presence of variant discrepancy from the residual for all observation on the entire regression model. The prerequisite that must be fulfilled in the regression model is the absence of heteroscedasticity indications.

There are some test methods that can be used, among them are the observation of scatterplots chart pattern and Spearman's Rho correlation coefficient test. 


\section{Scatterplots Chart Pattern}

This method involves the observation of scatterplot chart between standardized predicted value (ZPRED) and studentized residual (SRESID). The existence of certain pattern in the scatterplot chart between SRESID and ZPRED where $Y$ axis is the $Y$ which has been predicted and $X$ axis is the residual (predicted $Y-$ real $Y$ ).

The bases for the decision are :

- If certain patterns such as dots that form certain regular pattern (wavy, widened and then narrowed) exist, then heteroscedasticity has happened.

If there is no clear pattern, such as the spots that spread above and under zero on $Y$ axis, then there is no heteroscedasticity.

Scatterplot

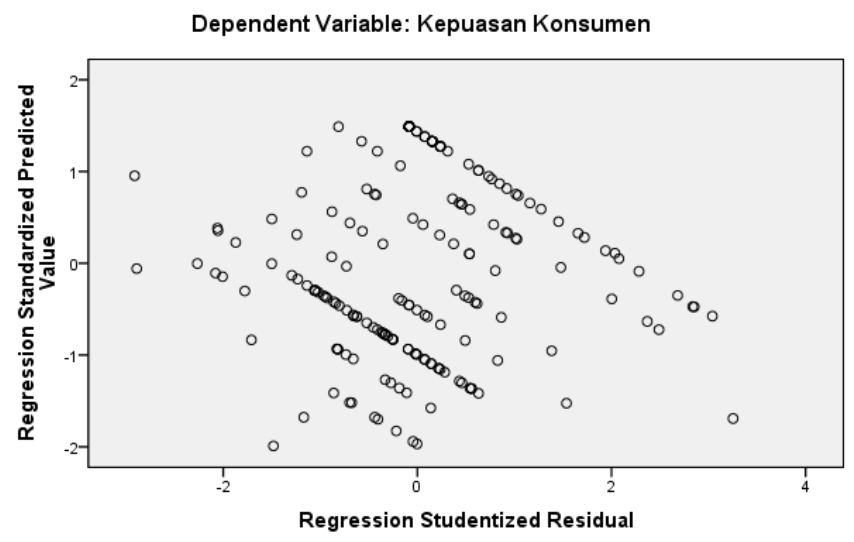

Picture 2.The Distribution of Regression Residual

The chart of regression residual above shows the spots that are scattered randomly and form no particular pattern. This means that there is no heteroscedasticity on regression model, hence the regression model can be properly used.

Spearman's Rho Correlation Coefficient Test

This method correlates independent variables with unstandardized residual value. The test employs 0,05 significance level with two tailed test. If the correlation between independent variables and residuals resulted in more than 0.05 significance, it can be declared that there is no heteroscedasticity problem in the regression model.

Table 6. Spearman's Rho Correlation Coefficient Test

\begin{tabular}{llcccccc}
\hline & & Security & $\begin{array}{c}\text { Perceived } \\
\text { usefulness }\end{array}$ & $\begin{array}{c}\text { Perceived } \\
\text { ease of use }\end{array}$ & $\begin{array}{c}\text { Service } \\
\text { quality }\end{array}$ & $\begin{array}{c}\text { Internet } \\
\text { banking } \\
\text { consumer } \\
\text { satisfaction }\end{array}$ & $\begin{array}{c}\text { Unstandard } \\
\text { ized } \\
\text { Residual }\end{array}$ \\
\hline Security & $\begin{array}{l}\text { Correlation } \\
\text { Coefficient }\end{array}$ & 1.000 & $.569^{* *}$ & $.541^{* *}$ & $.693^{* *}$ & $.708^{* *}$ & .021 \\
$\begin{array}{l}\text { Sig. (2- } \\
\text { tailed) }\end{array}$ &. & .000 & .000 & .000 & .000 & .764 \\
$\mathrm{~N}$ & 200 & 200 & 200 & 200 & 200 & 200 \\
\hline
\end{tabular}




\begin{tabular}{|c|c|c|c|c|c|c|c|}
\hline \multirow[t]{3}{*}{$\begin{array}{l}\text { Perceived } \\
\text { usefulness }\end{array}$} & $\begin{array}{l}\text { Correlation } \\
\text { Coefficient }\end{array}$ & $.569^{* *}$ & 1.000 & $.751^{* *}$ & $.648^{* *}$ & $.640^{* *}$ & .073 \\
\hline & $\begin{array}{l}\text { Sig. (2- } \\
\text { tailed) }\end{array}$ & .000 & . & .000 & .000 & .000 & .307 \\
\hline & $\mathrm{N}$ & 200 & 200 & 200 & 200 & 200 & 200 \\
\hline \multirow[t]{3}{*}{$\begin{array}{l}\text { Perceived } \\
\text { ease of use }\end{array}$} & $\begin{array}{l}\text { Correlation } \\
\text { Coefficient }\end{array}$ & $.541^{* *}$ & $.751^{* *}$ & 1.000 & $.723^{* *}$ & $.705^{* *}$ & .110 \\
\hline & $\begin{array}{l}\text { Sig. (2- } \\
\text { tailed) }\end{array}$ & .000 & .000 & . & .000 & .000 & .119 \\
\hline & $\mathrm{N}$ & 200 & 200 & 200 & 200 & 200 & 200 \\
\hline \multirow[t]{3}{*}{$\begin{array}{l}\text { Service } \\
\text { quality }\end{array}$} & $\begin{array}{l}\text { Correlation } \\
\text { Coefficient }\end{array}$ & $.693^{* *}$ & $.648^{* *}$ & $.723^{* *}$ & 1.000 & $.741^{* *}$ & .087 \\
\hline & $\begin{array}{l}\text { Sig. (2- } \\
\text { tailed) }\end{array}$ & .000 & .000 & .000 & . & .000 & .223 \\
\hline & $\mathrm{N}$ & 200 & 200 & 200 & 200 & 200 & 200 \\
\hline \multirow{3}{*}{$\begin{array}{l}\text { Internet } \\
\text { banking } \\
\text { consumer } \\
\text { satisfaction }\end{array}$} & $\begin{array}{l}\text { Correlation } \\
\text { Coefficient }\end{array}$ & $.708^{* *}$ & $.640^{* *}$ & $.705^{* *}$ & $.741^{* *}$ & 1.000 & $.578^{* *}$ \\
\hline & $\begin{array}{l}\text { Sig. (2- } \\
\text { tailed) }\end{array}$ & .000 & .000 & .000 & .000 & & .000 \\
\hline & $\mathrm{N}$ & 200 & 200 & 200 & 200 & 200 & 200 \\
\hline
\end{tabular}

The output above shows that the value of correlation between independent variable and Unstandardized Residual possesses significance value of more than 0,05. Because the significance is more than 0,05 , it can be concluded that there is no heteroscedasticity problem in the regression model.

\section{Autocorrelation Test}

Autocorrelation test is used to investigate the existence of deviation in autocorrelation classic assumption, that is the correlation which happens between residuals from one observation and other observation in regression model. The prerequisite that has to be met is the absence of autocorrelation in regression model. The test method to be used is Durbin-Watson Test with the condition that when the correlation value is between -2 and 2 then there is no autocorrelation happens.

Table 7 below shows that there is no autocorrelation among independent variable (Xi) and dependent variable (Y). This is due to the fact that between independent variable (Xi) and dependent variable $(\mathrm{Y})$ there is a correlation value of 1,933 which is in the range of -2 to 2.

Table 7. Autocorrelation Test Result Among Independent Variables (Xi) Towards Dependent Variables (Y)

\begin{tabular}{rrrrrrrr}
\hline & \multicolumn{7}{c}{ Change Statistics } \\
\cline { 2 - 6 } Model & R Square Change & F Change & df1 & df2 & Sig. F Change & Durbin-Watson \\
\hline 1 & .692 & 109.412 & 4 & 195 & .000 & 1.933 \\
\hline
\end{tabular}

\section{Linearity Test}

Linearity test aims to investigate the existence of significant linear correlation between two variables. This test is generally used as the prerequisite in linear or correlation regression analysis. The test was done with SPSS by using Test for Linearity with the level of 
significance at 0,05 . Two variables can be considered as having linear relationship when the significance (Linearity) is less than 005.

Table 8. Linearity Test (Internet Banking Consumer Satisfaction *Security)

\begin{tabular}{|c|c|c|c|c|c|c|c|}
\hline & & & $\begin{array}{l}\text { Sum of } \\
\text { Squares }\end{array}$ & df & $\begin{array}{l}\text { Mean } \\
\text { Square }\end{array}$ & $\mathbf{F}$ & Sig. \\
\hline \multirow{5}{*}{$\begin{array}{l}\text { Internet banking } \\
\text { consumer } \\
\text { satisfaction * } \\
\text { Security }\end{array}$} & Between & (Combined) & 649.383 & 11 & 59.035 & 19.505 & .000 \\
\hline & & Linearity & 632.362 & 1 & 632.362 & 208.931 & .000 \\
\hline & & $\begin{array}{l}\text { Deviation from } \\
\text { Linearity }\end{array}$ & 17.021 & 10 & 1.702 & .562 & .843 \\
\hline & & Within Groups & 569.012 & 188 & 3.027 & & \\
\hline & & Total & 1218.395 & 199 & & & \\
\hline
\end{tabular}

The table above shows that significance value for Linearity is 0,000 . Since the significance is less than 0,05 , it can be concluded that there is a linear correlation between internet banking consumer satisfaction variable and security variable

Table 9. Linearity Test (Internet Banking Consumers Satisfaction *Perceived usefulness)

\begin{tabular}{|c|c|c|c|c|c|c|}
\hline & & $\begin{array}{l}\text { Sum of } \\
\text { Squares }\end{array}$ & df & $\begin{array}{l}\text { Mean } \\
\text { Square }\end{array}$ & $\mathbf{F}$ & Sig. \\
\hline \multirow{8}{*}{$\begin{array}{ll}\text { Internet banking } & \text { Between } \\
\text { consumer } & \text { Groups } \\
\text { satisfaction* } & \\
\text { Perceived } & \\
\text { Usefulness } & \end{array}$} & (Combined) & 531.473 & 8 & 66.434 & 18.472 & .000 \\
\hline & & & & & & \\
\hline & Linearity & 489.819 & 1 & 489.819 & 136.195 & .000 \\
\hline & & & & & & \\
\hline & Deviation from & 41.654 & 7 & 5.951 & 1.655 & .122 \\
\hline & Linearity & & & & & \\
\hline & Within Groups & 686.922 & 191 & 3.596 & & \\
\hline & Total & 1218.395 & 199 & & & \\
\hline
\end{tabular}

The table above shows that the significance value of the Linearity is 0,000 . Since the significance is less than 0,05 , it can be concluded that there is a linear correlation between internet banking consumer satisfaction variable and perceived usefulness variable.

Table 10. Linearity Test (Internet Banking Consumer Satisfaction *Perceived Ease of Use)

\begin{tabular}{|c|c|c|c|c|c|c|c|}
\hline & & & $\begin{array}{l}\text { Sum of } \\
\text { Squares }\end{array}$ & df & $\begin{array}{c}\text { Mean } \\
\text { Square }\end{array}$ & $\mathbf{F}$ & Sig. \\
\hline \multirow{7}{*}{\multicolumn{2}{|c|}{$\begin{array}{ll}\text { Internet banking } & \text { Between } \\
\text { consumer } & \text { Groups } \\
\text { satisfaction * } & \\
\text { Perceived Ease } & \\
\text { of Use } & \end{array}$}} & (Combined) & 672.620 & 9 & 74.736 & 26.018 & .000 \\
\hline & & & & & & & \\
\hline & & Linearity & 611.500 & 1 & 611.500 & 212.881 & .000 \\
\hline & & & & & & & \\
\hline & & $\begin{array}{l}\text { Deviation from } \\
\text { Linearity }\end{array}$ & 61.120 & 8 & 7.640 & 2.660 & .009 \\
\hline & & Within Groups & 545.775 & 190 & 2.872 & & \\
\hline & & Total & 1218.395 & 199 & & & \\
\hline
\end{tabular}


The table above shows that the significance value of Linearity is 0,000. Since the significance is less than 0,05 , it can be concluded that there is linear correlation between internet banking consumer satisfaction variable and perceived ease of use variable.

Table 11. Linearity Test (Internet Banking Consumer Satisfaction *Service Quality)

\begin{tabular}{|c|c|c|c|c|c|c|c|}
\hline & & & $\begin{array}{l}\text { Sum of } \\
\text { Squares }\end{array}$ & df & $\begin{array}{l}\text { Mean } \\
\text { Square }\end{array}$ & $\mathbf{F}$ & Sig. \\
\hline \multirow{7}{*}{$\begin{array}{l}\text { Internet banking } \\
\text { consumer } \\
\text { satisfaction * } \\
\text { Service Quality }\end{array}$} & Between & (Combined) & 709.710 & 10 & 70.971 & 26.369 & .000 \\
\hline & Groups & & & & & & \\
\hline & & Linearity & 675.605 & 1 & 675.605 & 251.019 & .000 \\
\hline & & Deviation from & 34.105 & 9 & 3.789 & 1.408 & .187 \\
\hline & & Linearity & & & & & \\
\hline & & Within Groups & 508.685 & 189 & 2.691 & & \\
\hline & & Total & 1218.395 & 199 & & & \\
\hline
\end{tabular}

The table above shows that the value of significance of Linearity is 0,000 . Because the significance is less than 0,05 , it can be concluded that linear correlation exists between internet banking consumer satisfaction variable and service quality variable.

\section{Analysis Result of Multiple Linear Regression}

Multiple linear regression can be used to examine the direction of the correlation between independent variable and dependent variable, whether each variable is related positively or negatively, and to predict the value of the dependent variable when there is a fluctuation in the value of independent variable. The independent variables within this research are security, perceived usefulness, perceived ease of use, and service quality. On the other hand, the dependent variable is the satisfaction of consumers who use internet banking (Y). To estimate the regression coefficient, the data processing system is supported by SPSS 17.0 and the result that can be observed below:

Table 12. Regression Result Analysis

\begin{tabular}{|c|c|c|c|c|c|c|}
\hline & & \multicolumn{2}{|c|}{$\begin{array}{l}\text { Unstandardized } \\
\text { Coefficients }\end{array}$} & \multirow{2}{*}{$\begin{array}{c}\begin{array}{c}\text { Standardized } \\
\text { Coefficients }\end{array} \\
\text { Beta }\end{array}$} & \multirow[b]{2}{*}{$\mathbf{t}$} & \multirow[b]{2}{*}{ Sig. } \\
\hline \multicolumn{2}{|c|}{ Model } & B & Std. Error & & & \\
\hline \multirow[t]{5}{*}{1} & (Constant) & 1.299 & 1.139 & & 1.141 & .255 \\
\hline & Security & .327 & .052 & .354 & 6.234 & .000 \\
\hline & Perceived usefulness & .107 & .072 & .088 & 1.488 & .138 \\
\hline & Perceived ease of use & .297 & .068 & .288 & 4.396 & .000 \\
\hline & Service quality & .222 & .064 & .237 & 3.499 & .001 \\
\hline
\end{tabular}
is:

Based on the result of the analysis in table 12 above, the resulting regression equation

$$
Y=1,299+0,327 X_{1}+0,107 X_{2}+0,297 X_{3}+0,222 X_{4}
$$

Where :

$$
\begin{aligned}
& Y=\text { Internet banking consumer satisfaction } \\
& X_{1}=\text { Security } \\
& X_{2}=\text { Perceived Usefulness } \\
& X_{3}=\text { Perceived Ease of Use } \\
& X_{4}=\text { Service Quality }
\end{aligned}
$$


- The constant of 1,299 declares that if the value of security, perceived usefulness, perceived ease of use, and service quality is zero, then the value of internet banking consumer satisfaction is 1,299 .

- Regression coefficient of $\mathrm{X} 1$ which is 0,327 declares that for every $1 \%$ increase in value $($ marked by + ) the security variable will increase the value of internet banking consumer satisfaction by $32,7 \%$.

- Regression Coefficient of X2 which is 0,107 declares that for every $1 \%$ increase in value $($ marked by + ) the perceived usefulness variable will increase the value of internet banking consumer satisfaction by $10,7 \%$.

- Regression Coefficient of X3 which is 0,297 declares that for every $1 \%$ increase in value $($ marked by + ) the perceived ease of use variable will increase the value of internet banking consumer satisfaction by $29,7 \%$.

- Regression Coefficient of X3 which is 0,222 declares that for every $1 \%$ increase in value $($ marked by +$)$ the service quality variable will increase the value of internet banking consumer satisfaction by $22,2 \%$.

\section{Multiple Correlation (R) and Determination Analysis ( $\left.\mathbf{R}^{2}\right)$}

Multiple Correlation Analysis is used to investigate the correlation between two or more independent variables with dependent variables simultaneously. This coefficient shows the magnitude of the correlation between independent variables and dependent variables simultaneously. The value or $\mathrm{R}$ ranges from $0-1$, where a value closer to 1 indicates stronger relationship and vice versa.

According to Sugiyono (2007) the guideline to interpret the correlation coefficient is as follows:

$$
\begin{array}{ll}
0,00-0,199 & =\text { very weak } \\
0,20-0,399 & =\text { weak } \\
0,40-0,599 & =\text { average } \\
0,60-0,799 & =\text { strong } \\
0,80-1,000 & =\text { very strong }
\end{array}
$$

From the result of the regression analysis, which can be seen from model summary output, the result of multiple correlation analysis can be seen in the table below:

Table 13. The Result of Multiple Correlation Analysis

\begin{tabular}{lrrrr} 
Model & R & R Square & $\begin{array}{c}\text { Adjusted R } \\
\text { Square }\end{array}$ & $\begin{array}{c}\text { Std. Error of the } \\
\text { Estimate }\end{array}$ \\
\hline 1 & $.832^{\mathrm{a}}$ & .692 & .685 & 1.38775 \\
\hline
\end{tabular}

The table above shows that the value of $\mathrm{R}$ is 0,832 . This shows that there is a strong correlation between independent variables which include security, perceived usefulness, perceived ease of use, and service quality with the dependent variable, namely internet banking consumer satisfaction.

Determination analysis (R2) in multiple linear regression is used to investigate the percentage of contribution of influence given by independent variable simultaneously towards dependent variables.

If $\mathrm{R}^{2}=0$, then there is not the slightest percentage of influence contributed by independent variables towards dependent variables. In other words, the variation of independent variables used in the model does not give the slightest explanation to the variation of dependent variables. 
However, if $R^{2}=1$, then the percentage of influence contributed by independent variables towards dependent variable is perfect. In other words, the variation of independent variables used in the model explains the variation of dependent variable $100 \%$.

Adjusted $\mathrm{R}$ Square is the adjusted value of $\mathrm{R}$ Square which is always smaller than $\mathrm{R}$ Square, and this number may have negative value. According to Santoso (2001), Adjusted $R$ Square is used as determination coefficient for regression with more than two independent variables.

In Table 13 above, as shown by model summary output, the result of determination analysis is the value of Adjusted R Square (more than one independent variables) 0,685 or $68,5 \%$. It shows that the percentage of influence contributed by independent variables which include security, perceived usefulness, perceived ease of use, and service quality towards the variable of internet banking consumer satisfaction is $68,5 \%$. In other words, the variation of independent variables used in the model, which include security, perceived usefulness, perceived ease of use, and service quality can explain $68,5 \%$ of dependent variable variation (internet banking consumer satisfaction). The remaining 31,5\% is influenced or explained by other variables which are not included in this research model.

\section{Simultaneous Regression Coefficient Test (F Test)}

This test aims to investigate whether the independent variables simultaneously affect the dependent variables significantly. The output of regression analysis shows $\mathrm{F}$ value in the table below:

Table 14. F Test Result

\begin{tabular}{|c|c|c|c|c|c|c|}
\hline Model & & Sum of Squares & df & Mean Square & $\mathbf{F}$ & Sig. \\
\hline \multirow[t]{3}{*}{1} & Regression & 842.852 & 4 & 210.713 & 109.412 & $.000^{\mathrm{a}}$ \\
\hline & Residual & 375.543 & 195 & 1.926 & & \\
\hline & Total & 1218.395 & 199 & & & \\
\hline
\end{tabular}

Hypotheses :

$\mathrm{H}_{1} \quad$ : Positive influence exists simultaneously between security factor, perceived usefulness factor, perceived ease of use factor, and service quality factor with internet banking consumer satisfaction.

With the certainty level at 95\%, $\alpha=5 \%$, df $1=4$, and df $2(n-k-1)=195$, then $\mathrm{F}$ table $=2,418$. Because the value of $F$ count $>F$ table $(109,412>2,418)$, then $H_{1}$ is accepted. This means that there is a simultaneous positive influence between security factor, perceived usefulness factor, perceived ease of use factor, and service quality factor with internet banking consumer satisfaction. Therefore, it can be concluded that security factor, perceived usefulness factor, perceived ease of use factor, and service quality factor simultaneously affect the internet banking consumer satisfaction.

\section{Partial Regression Coefficient Test (t Test)}

This test aims to investigate whether independent variables regression model partially influence dependent variables significantly. From the result of regression analysis output, the value of $t$ can be observed in the table below:

Table 15. $t$ Test Result

\begin{tabular}{|c|c|c|c|c|c|}
\hline \multirow[b]{2}{*}{ Model } & \multicolumn{2}{|c|}{$\begin{array}{l}\text { Unstandardized } \\
\text { Coefficients }\end{array}$} & \multicolumn{3}{|l|}{$\begin{array}{l}\text { Standardized } \\
\text { Coefficients }\end{array}$} \\
\hline & B & Std. Error & Beta & $t$ & Sig. \\
\hline
\end{tabular}




\begin{tabular}{|c|c|c|c|c|c|c|}
\hline \multirow[t]{5}{*}{1} & (Constant) & 1.299 & 1.139 & & 1.141 & .255 \\
\hline & Security & .327 & .052 & .354 & 6.234 & .000 \\
\hline & Perceived usefulness & .107 & .072 & .088 & 1.488 & .138 \\
\hline & Perceived ease of use & .297 & .068 & .288 & 4.396 & .000 \\
\hline & Service quality & .222 & .064 & .237 & 3.499 & .001 \\
\hline
\end{tabular}

\section{Security Variable Regression Coefficient Test}

Hypothesis:

$\mathrm{H}_{2}$ : Security factor positively influence internet banking consumer satisfaction.

Distribution table for $\mathrm{t}$ is calculated using $\alpha=5 \%: 2=2,5 \%$ (two tailed test), with $\mathrm{df}(\mathrm{n}-\mathrm{k}-1)=195$. With two tailed test, the result acquired for $\mathrm{t}$ table is 2,259 . Because the value of $\mathrm{t}$ count $>\mathrm{t}$ table $(6,234>2,259)$, hence $\mathrm{H}_{2}$ is accepted. This means, security factor partially affects internet banking consumer satisfaction positively.Therefore, it can be concluded that partially, security variable affects internet banking consumer satisfaction. This shows that the better the level of security offered by the provider of internet banking facility, the higher the level of satisfaction experienced by the user of internet banking.

\section{Perceived Usefulness Variable Regression Coefficient Test} Hypothesis:

$\mathrm{H}_{3}$ : Perceived ease of use factor positively influenceinternet banking consumer satisfaction

Distribution table for $\mathrm{t}$ is calculated using $\alpha=5 \%: 2=2,5 \%$ (two tailed test), with $\mathrm{df}(\mathrm{n}-\mathrm{k}-1)=195$. With two tailed test, the result acquired for $\mathrm{t}$ table is 2,259 . Because the value of $\mathrm{t}$ count $<\mathrm{t}$ table $(1,488<2,259)$, hence $\mathrm{H}_{3}$ is rejected. This means that partially, perceived usefulness factor does not have positive influence towards internet banking consumer satisfaction. Therefore, it can be concluded that partially perceived usefulness variable doesn't affect the variable of internet banking consumer satisfaction. This shows that the usefulness of internet banking does not always influence the level of satisfaction for the consumer who uses internet banking.

\section{Perceived Ease of Use Variable Regression Coefficient Test}

Hypothesis:

$\mathrm{H}_{4} \quad$ : Perceived ease of use factor positively influence internet banking consumer satisfaction

Distribution table for $\mathrm{t}$ is calculated using $\alpha=5 \%: 2=2,5 \%$ (two tailed test), with $\mathrm{df}(\mathrm{n}-\mathrm{k}-1)=195$. With two tailed test, the result acquired for $\mathrm{t}$ table is 2,259 . Because the value of $\mathrm{t}$ count $>\mathrm{t}$ table $(4,369>2,259)$, hence $\mathrm{H}_{4}$ is accepted. This means that partially, perceived ease of use factor affects the factor of internet banking consumer satisfaction positively. Therefore, it can be concluded that partially, perceived ease of use variable affects internet banking consumer satisfaction variable. This shows that the easier the use of internet banking, the higher the satisfaction factor experienced by users of internet banking.

Service Quality Variable Regression Coefficient Test Hypothesis

$\mathrm{H}_{5} \quad$ : Service quality factor positively influences the factor of internet banking consumer satisfaction

Distribution table for $\mathrm{t}$ is calculated using $\alpha=5 \%: 2=2,5 \%$ (two tailed test), with $\mathrm{df}(\mathrm{n}-\mathrm{k}-1)=195$. With two tailed test, the result acquired for $\mathrm{t}$ table is 2,259 . Because the value of $t$ count $>t$ table $(3,499>2,259)$ hence $\mathrm{H}_{5}$ is accepted. This means that partially, service quality factor positively affect the factor of internet banking consumer satisfaction. Therefore, it can be concluded that partially, service quality variable influences the variable of internet 
banking consumer satisfaction. This shows that the better the service quality offered by the banks that provide internet banking service, the higher the satisfaction experienced by the users.

\section{CONCLUSION AND SUGGESTION \\ Conclusion}

The following conclusions are drawn based on the result of the analysis and the discussion:

1) Security variable, perceived usefulness variable, perceived ease of use variable, and service quality variable simultaneously influence the variable of internet banking consumer satisfaction. This shows that all four variables affect the factor of internet banking consumer satisfaction.

2) Security factor positively influences the satisfaction of consumers who use internet banking. This shows that the better the level of security offered by the provider of internet banking facility, the higher the level of satisfaction experienced by the user of internet banking.

3) Perceived usefulness factor does not have positive influence towards internet banking consumer satisfaction. This shows that the usefulness of internet banking does not always influence the level of satisfaction for the consumer who uses internet banking.

4) Perceived ease of use factor positively influences the satisfaction of consumers who use internet banking. This shows that the easier it is to use internet banking, the higher the satisfaction factor experienced by users of internet banking.

Service quality factor positively influences the satisfaction of consumers who use internet banking. This shows that the better the service quality offered by the banks that provide internet banking service, the higher the satisfaction experienced by the users.

\section{REFERENCES}

Ahmad. Bambang Setiyo Pambudi. 2014. Pengaruh persepsi manfaat, persepsi kemudahan, keamanan dan ketersediaan fitur terhadap minat ulang nasabah bank dalam menggunakan internet banking (studi pada program layanan Internet banking BRI). Jurnal Studi Manajemen. Vol. 8 No. 1. April 2014.

Beer, Stan. 2006. Customers Preference on Internet Banking, Survey (Retrieved from http://www.itwire.com/content/view/4570/53 on March 20, 2009).

Chaffey, D; Mayer, R; Johnson, K and Ellis Chadwick, F. 2006. Internet Marketing: Strategy, Implementation and Practice, (3rd Edition) Financial Times/Prentice Hall, Harlow, Essex, U.K, $8-10$.

Davis, F.D. 1989. Perceived Usefullness, Perceived Ease of Use of Information Technology. Management Information System Quarterly, 13(3): 319-340.

Huda, Ahmad Nurul. Sri Wahyuni. 2012. Analisis Pengaruh Kualitas Layanan Internet Banking dan Tingkat Kepuasan Terhadap Loyalitas Nasabah pada PT Bank Rakyat Indonesia (Persero) Tbk Kantor Cabang Pembantu Jamsostek Jakarta. Jurnal Business and Management Review. Vol. 2 No. 2. Juni 2012.

Karen Furst, et.al, "Internet Banking: Development and Prospects," Program on Information Resources Policy Harvad Offers Internet Banking, "Quarterly Journal, Vol. 19 No. 2 June 2000, hal. 30. 
Kasmir, Dr. 2014. Bank dan Lembaga Keuangan Lainnya. Edisi revisi 2014. PT Rajagrafindo Persada. Jakarta. Cetakan ke-15.

Khan, M S; S. S. Mahapatra and Sreekrumah. 2009. Service Quality Evaluation in Internet Banking: An Empirical Study in India. International Journal of Indian Culture and Business Management, 2(1), $30-46$.

Kotler, Philip. Kevin Lane Keller. 2008. Manajemen Pemasaran. ed 12 jilid 2. PT Indeks, cetakan II.

Langelo, Andretha S.E. 2013. Perceived Usefulness, Perceived Ease of Use, Perceived Risk Impact to Lecturers' Internet Banking Adoption. Jurnal EMBA. Vol. 1 No. 4. Desember 2013. Hal 1571-1580.

Ozuru, H. N; Chikwe, J. E and Idika Uduma. 2010. The use of Traditional payments and electronic payments systems in Nigeria: A discourse. Proceedings of the 11th Annual Conference of International Academy of African Business and Development.

Priyatno, Duwi. 2008. Mandiri Belajar SPSS Untuk Analisis Data dan Uji Statistik. Cetakan Pertama. Yogyakarta: Mediakom.

Rahardjo, Budi. 2002. Keamanan Sistem Informasi Berbasis Internet. PT Insan Infonesia Bandung \& PT INDOCISC - Jakarta.

Saputro. Sukirno. 2013. Pengaruh Persepsi Kemudahan Penggunaan, Kepercayaan, Kecemasan Berkomputer dan Kualitas Layanan Terhadap Minat Menggunakan Internet Banking. Jurnal Nominal. Vol. II No. 1. 2013.

Singhal, D and V. Padhmanabhan. 2008. A Study on Customer Perception Towards internet Banking: Identifying major contributing factors. The Journal of Nepalese Business Studies. V (1), $101-111$.

Sugianto. Vivi. 2014. Analisis Pengaruh Technology Acceptance Model (TAM) Dan Perceived Enjoyment Terhadap Kepuasan Konsumen Pengguna M-Business. Jurnal Manajemen Motivasi. Vol. 10 No.1. Februari 2014.

Sugiyono. 2006. Statistika untuk Penelitian. Bandung: CV. Alfabeta.

Sugiyono. 2010. Metode Penelitian Bisnis (Pendekatan Kuantitatif, Kualitatif dan R \& D. Bandung: Penerbit Alfabeta.

Sulastini, Ni Putu. I Gde Ketut Warmika. 2014. Aplikasi TAM, Persepsi Resiko, dan Kepercayaan Dalam Menjelaskan Niat Menggunakan Internet Banking. E-Jurnal Manajemen Universitas Udayana Vol. 3 No. 4. 2014.

Suprapto, Fitria Magdalena. 2014. Pengaruh Persepsi Keamanan Web dan Kesesuaian Lifestyle terhadap Minat Penggunaan Internet Banking : Technology Acceptance Model yang dimodifikasi. Jurnal Ilmiah Mahasiswa FEB Universitas Brawijaya. Vol. 2 No. 2. Semester genap 2013/2014.

Tjiptono, Fandy. 2007. Manajemen Jasa. Yogyakarta: ANDI. 
Yusnaini. 2010. Pengaruh Kualitas Pelayanan Internet Banking Terhadap Kepuasan dan Loyalitas Konsumen pada Bank Swasta. Jurnal Dinamika Akuntansi. Vol. 2 No. 1. Maret 2010. Hal. 1-9.

Undang-Undang RI Nomor 10 tahun 1998 Tentang Perubahan Atas Undang-Undang Nomor 7 Tahun 1992 tentang Perbankan

Buletin Ekonomi Moneter dan Perbankan, Juni 2002.

http://bisniskeuangan.kompas.com/read/2012/09/25/09282361/Memaksimalkan.Internet. Banking.

http://economy.okezone.com/read/2017/03/21/320/1648501/bank-mandiri-incarpengguna-nasabah-online-tembus-2-5-juta

https://ekbis.sindonews.com/read/1172393/178/pengguna-e-banking-meningkat-tajam1484822191

http://puskakom.ui.ac.id/publikasi/rilis-pers-hasil-survey-profil-pengguna-internet-diindonesia-2014-oleh-apjii-bekerja-sama-dengan-pusat-kajian-komunikasi-universitasindonesia.html

https://sharingvision.com/2014/07/nilai-transaksi-internet-banking-lebih-besar-dari-atmdan-kartu-kredit/

https://sharingvision.com/2015/05/pertumbuhan-internet-banking-di-indonesia/

http://www.marsindonesia.com/newsletter/34-nasabah-sudah-melek-internet-banking 